\title{
SUPPLY OF LABORATORY ANIMALS
}

A MEETING of representatives of the supporting societies of the Laboratory Animals Bureau of the Medical Research Council Laboratories, Hampstead, was held at the Royal Society of Medicine on January 22, with Dr. R. Lovell in the chair. The purpose of the meeting was to discuss a paper on "The Supply of Laboratory Animals", by Dr. W. Lane-Petter, the director of the Bureau; the paper had been circulated in advance. The Laboratory Animals Bureau has been established for nearly six years, and already it has gathered much useful, and some alarming, information on the sources of the animals used by physiologists, pharmacologists, etc., in their research work or in their work on the standardization of drugs and sera.

Each year the Home Secretary lays before Parliament a "Return of Experiments performed under the Act 39 and 40 Vict., C. 77'. Dr. Lane-Petter's paper quotes the figures in the returns for the years 1939-51. They rise steadily from $\mathbf{9 5 4 , 6 9 1}$ for 1939 to $1,919,424$ for 1951, and these figures do not include animals which are not returnable under the Act-for example, the control animals where only those of the experimental group are subjected to procedures "calculated to cause pain", most pregnancy-diagnosis tests, and procedures for the production of sera or other substances obtained from animals for medical, veterinary or scientific purposes. An analysis of figures obtained from various sources (inevitably not very accurate) indicates that mice constitute about 79 per cent of the total number of animals used, involving about 43 per cent of the total cost of the animals. The corresponding figures for rats are 8 and 9 per cent, respectively, for guinea pigs 6 and 18 per cent respectively and, at the other end of the table, for monkeys 0.1 and 7 per cent respectively. A table gives the main uses for which the various species are required : applied medicine (diagnosis of disease, pregnancy tests, serum preparation, serum titration, bio-assay and toxicity tests); and research and teaching (physiology, biochemistry, pharmacology, bacteriology and parasitology, endocrinology, nutrition, experimental surgery and teaching). It indicates that research uses the more expensive animals and that applied medicine has adopted the cheaper animals. These are the costs of the animals before being submitted to any experimental procedure. The behaviour of the animals during their laboratory existence has sometimes shown that it is more economical in the end to buy more expensive but really healthy animals than cheaper, less healthy ones. Nearly always home breeding is more expensive than buying from dealers (it would be prohibitive for dogs), and the advantages accruing from such must be weighed against the cost. The commercial breeder probably has lower overhead charges than the scientific breeder, he is probably a better business man and is much more of a specialist in his job. On the other hand, where litter-mate animals are required or animals from parents with a special dietary history, the only absolutely reliable way of obtaining them is by home-breetling; and when mice are required for virus chemotherapy or other virological research, they must be produced under conditions too exacting for commercial breeders.
The procuring of animals which are not specially bred by either a commercial breeder or by the laboratory needing them has some difficulties-for example, monkeys are best imported during the warm months, amphibians are most prolific in the late summer, and guinea pigs are often scarce in the early months of the year. Workers may therefore have to plan to carry out their work when supplies are likely to be good. Heavy demands for the more prolific animals, and especially of young ones, can only be met if orders are placed well beforehand to allow extra matings to be made.

It has been suggested that a general breeding station should be established for the supply of animals to the whole of a university or even to groups of universities. This might or might not have some financial advantage; it would certainly have many disadvantages, for, according to a simple principle of public health, the larger the colony the greater the chance of infection coming in and the less the chance of getting rid of it. Another suggestion which can scarcely be taken seriously is that there should be some centralized depot which would receive animals from all sources and distribute them as needed. The objections to this are the obvious difficulties of controlling the supply and demand, the possibility of infection and the slow adjustment of most animals to change of environment.

On the whole, it appears that most needs can be met from commercial sources and that the acquiring of animals from such sources will be more economical than breeding in the laboratory. It is, however, obviously desirable that some recognized authority should be familiar with the various breeding stations, the strains of animals available and their general condition. It should be able to recommend an alternative source of animals to a worker whose usual source has suddenly become unable to supply his needs. Such a central authority does, in fact, already exist in the Laboratory Animals Bureau. Much has already been done; but much remains to be done to encourage different breeders to produce well-defined strains and perhaps to improve existing strains on the lines used in farm-stock practice for upgrading.

The desirability of using 'inbred' strains of such animals as mice is questioned. The Bureau has discovered that many breeders who claim to supply inbred mice do not, in fact, know the real meaning of the term 'inbred', and, until information based on unquestionable 'inbred' strains is obtained, no reliable conclusion as to their desirability can be drawn. It has also been found that it is practically impossible to keep a colony of animals strictly infection-free, but that a high standard of hygiene will keep a colony healthy enough for most purposes.

To enlarge the supply of cats and dogs, strong plea is put forward that the humane societies should hand over the really unwanted and ownerless animals that they acquire, for these societies are in a much stronger position than dealers and laboratory workers for ensuring that the cats and dogs which they collect are, in fact, unwanted and ownerless.

The discussion of the paper was opened by Prof. R. E. Glover, representing the Royal College of 
Veterinary Surgeons, who approved of the Bureau's scheme of accreditation of breeders but emphasized the dangers of enlarging colonies beyond the limits of the personal care by the owner--for example, the increased danger of infection, and the possibly less carcful treatment by subordinate staff. The operation of demand versus supply may be leading to price competition and the consequent annihilation of the smaller breeder whose contribution is useful and often very good. Prof. Glover maintained that cost in research work is indeed watched carefully, but the use of expensive animals as well as the cheaper ones has to be investigated in order to discover the best animal for the purpose in view. Commercial firms benefit by the experience of research workers when they take up large-scale production and test their own products. To overcome the difficulty of having a surplus of young animals at a time of year when they are least wanted, he suggested that a large proportion of these young animals in the glut season should be put to breeding so that the total production in the less good breeding season should, in fact, be increased. He thought that decentralization is distinctly advantageous, but that institutes run by universities on not too large a scale by competent scientific workers would afford a chance of studying animal husbandry and animal diseases ; the institutes could train really good technicians, and each institute might specialize in one or two particular species. The linking-up of such institutes would obviously be valuable. Prof. Glover pleaded for more investigations into epidemics in animal colonies, particularly those of commercial breeders. A well-qualified research worker associated with some institute where he would have contact with clinicians, bacteriologists, etc., would be able to do most valuable work on animal epidemics.

Dr. C. C. N. Vass, representing the Physiological Society, emphasized the fact that expenditure on animals must be faced. Often the difficulty in experiments on cats and dogs is to get them of a known age. If this could be done by paying a higher price, it must be paid, and, since such an animal might be under observation for two years, the high price would be justifiable and in fact almost negligible.

Dr. H. J. Parish, representing the Pathological Society, agreed to the need of using healthy animals at almost any cost, particularly for such long-time experiments as are involved in work on prophylactics, which work, it might be stressed, is often done for the benefit of animals and not only for human beings.

Dr. S. J. Folley, representing the Biochemical Society, asked if the possibility of using rats in place of cats and dogs has been considered as carefully as possible; but Dr. Vass replied that, for teaching purposes, the rat is often too small an animal.

In reply, Dr. Lane-Petter said that if breeders' colonies are to be larger, they should be housed in separate small buildings; that prices are becoming stabilized; that putting surplus stock in the summer to breeding purposes would bo workable; and that, if institutes for animal breeding should be set up by universities, they cannot be expected to produce all the animals needed. He mentioned again the work of the Bureau in visiting conmercial breeders and in giving advice on the healthy running of the colonies.

Great appreciation of Dr. Lane-Petter's paper was expressed, and it was unanimously decided that it should be published in extenso or even onlarged, if possible in one of the scientific review journals.

\section{STUDY OF THE BRITISH FLORA DURING 1952}

11

THE discovery, in remote parts of Scotland in recent years, of easily recognized plants such as Konigia islandica L. and Diapensia lapponica L. ${ }^{1}$ is sufficient indication that there are still large areas in the British Isles awaiting botanical investigation. During 1952 two more species of northern distribution well known in Scandinavia have been added to our flora.

The finding by Sir Christopher Cox of Artemisia norvegica Fr. in north-west Scotland in August has already been announced ${ }^{2}$. Known only from Norway and the northern Urals, it belongs to a circumpolar group of closely related species which are very unlike representatives of the genus previously known from Britain. The other outstanding addition to our list of native species in 1952 is that of a sedge which appears in current Scandinavian literature as Carex pulchella (Lönnr. $)^{3-5}$. It is allied to $C$. serotina Mérat (C. Oederi auct.), and has been brought to the notice of workers in Britain by Miss E. W. Davies (University College, Leicester). During the summer she found it in several localities in Perthshire and north-west Scotland, and there are specimens in herbaria collected earlier. For reasons of nomenclature she proposes to publish the discovery under an appropriate name which is not the one by which it is known in Scandinavia.

At the annual exhibition meeting of the Botanical Society of the British Isles, arranged in the lecture room of the British Museum (Natural History) (by kind permission of the trustees) on November 29, Artemisia norvegica was represented by Norwegian material exhibited by the Department of Botany of the Museum, and Carex pulchella by Scottish material in an exhibit prepared by Miss Davies.

Another addition claimed during the year is Cakile edentula (Bigel.) Hook. from the coast of north Scotland, the Outer Hebrides and Shotland ${ }^{6}$. Löve has shown that while the British Cakile maritima Scop. (which is diploid) ranges around the whole coast of Europe and the Mediterranean, the tetraploid North American $C$. edentula occurs in Iceland and the Azores ${ }^{2}$. D. E. Allen (University of Cambridge) exhibited at the meeting British material determined as representing the two species, with drawings illustrating the characters of the leaves and fruits. A sedge from Ben Lawers which appears to be allied to Carex parallela (Læst.) Sommerf. ${ }^{8}$ shown by N. Y. Sandwith (Royal Botanic Gardens, Kew), and an unnamed Euphrasia from Caithness displayed by Dr. E. F. Warburg (Department of Botany, University of Oxford) may, on further investigation, also prove new. An interesting hybrid between Rumex conglomeratus Murray and th naturalized South Amsrican Rumex cuneifolius, Campd., collected by Dr. F. R. Elliston. Wright at Braunton Burrows, North Devon, and shown by J. E. Lousley, is apparently new to science.

The exhibition also included examples of important re-discoveries or extensions of range. One of the most interesting of these was Ononis reclinata $\mathrm{L}$. collected last June by Miss H. M. Bigwood on the limestone of the Gower Peninsula. The locality is likely to be the one at which it was found by D. Sharpe on September 18, $1828^{\circ}$, where, in spite of soarchos by competent botanists, it has not been seen since that date. The only other stations on the mainland are the well-known one in Devon, and the 